\title{
「こしき」と「蒸し」について (続報)
}

\section{永 谷 正 治*}

前報（本誌第 56 巻 9 号）に対して各方面より御質問 や参考意見が女り，特に第 57 巻 1 号には松本千春氏の 御意見がのせられました。それで前報で推論を複雑にし ないために省略した種々のファクター，およびその後に おいて補足した要因などを披歴して敃答にしたと思いま †े

白己弁護めいて恐縮ですが，前稿において私がこれら のファクターを省略したのは飽くまで問題を物理的に解 釈し, 現象数量化するためであって，それによって実 際に生ずる現象の理論的な近似值を得ようとしたのであ ります。物理学の領域ではこういったやり方は定石で, 例壳ば真空中に括ける質点の運動を考えることが力学の 基礎となり，また完全気体という想定が今日の熱力学を 生んだ等であります。

そこで今度は現実の場において理論を適用するときに は場合に応じて種々の原理を組み合わせて補正する必要 が生じますが，大気中で物体を落下させる場合，真空を 仮定して求的られた落体の法則が準用されるように, 原 理は生きているに違いありません。

前稿において問題を蒸気と米の熱収支, 水分収支のみ に限り,いわば理想状態の『蒸し』を取扱いましたの で，ここに種々の補正因子を加えて実際との一致に近づ けたいと思います。なお推論に不備の点がありました ら，扣手数ですが再び御指摘下さるよう拓願いいたしま 于。

\section{「強い蒸気」が存在しないと考えた理由}

前稿に扣いて述べたものを要約すると, 強い蒸気とは

1. 蒸気量ではない。

2. 圷力ではない。

3. 過熱蒸気ならば条件にかなう。 過熱蒸気の成因は

1. 釜の過熱部分による作用。

* 札幌国税局鑑定官室

第 57 巻 第 3 号
2. 断熱膨張後の性質。

このいずれも条件としては不十分なため『強い蒸気』 は存在しないと考えた。実際の蒸しなり蒸米について蒸 気の強さをこのような物理量だけに求めるのは行き過ぎ であるとの反論もあったが我々が、ニントロールし得る ものは結局物理量だけであり，物理量を管理しても所定 の『強い蒸気』が得られなければ, そんなものは存在し ないと考えるのが最も合理的である。

\section{膨張の際の仕事について}

菘本氏の御意見中，「蒸気忱この場合外部に対して何 等の仕事をするものではない」とあるのは不審に思う。 勿論この際，蒸気はピストンを押寸等目に見える仕事を している訳ではないが，いかなる膨張でも外圧が完全真 空でない限り，外圧Pに対して膨張分Vだけの仕事をし なければならず，従って膨張後の蒸気はその前の含熱量 より $\mathrm{P} ・ \mathrm{~V}$ だけ少くなるはずである。この点を御検討願 いたい。

\section{復水した水分が米粒を伝わって 落ちるという考え}

この点は以前から懸念していたが，コシキの内側を伝 わって復水分が流れ落ちることは観察し得るが，その内 部つまり米粒間部ではどうなっているのか確認の方法も なく，また蒸気量を少くして水の流下を妨げない条件で 蒸しても特に上層の蒸米が軽くなることもないので, ご く大ざっぱに考えて米粒を暖めて復水した水分は乞の米 粒に吸収されるまで粒面に被膜状になって留まり得ると した。勿論この段階では附着水は表面張力によって近接 の米粒へ移動可能である。

コシキ内吸水量を浸漬米の比熱と温度から求めるとい う考え方は，上の条件を仮定してはじめて成立するもの であるが，正確なこと棒験によって求めなくてはなら ず，また蒸しの他の条件を乱さないでコシキ中央部の蒸 
米を観察することも困難である。これ等のことを考虑し てこの問題はあまり大きなファクターではないと判断し た次第である。

\section{同伴飛沫の問題}

過熱蒸気が生じないとすれば蒸しに用いる蒸気は水滴 を全く含まない即ち乾燥度 $100 \%$ を限度とし，それよ りも湿った状態の飽和蒸気である。では同伴した飛沫は 何処へ行くかといえば大部分は米粒に付着すると考兄ら れる。米層で濾過される訳である。飛沫と蒸気の温度は 等しいから米との間に熱の出入は考えられない。またコ シキの底の部分ほど飛沫の付着が多いと考兄られるの で, 底の方の蒸米が重くなるのはもっぱらこのためであ ると推定している。

同伴飛沫の量は液の粘度, 表面張力, 比重等によって 影響を受けるが，特に大きいのは蒸発量である。狭い液 面から多く蒸発すればするほど飛沫は多くなる。従って カマドの火力を強くして蒝気量を増せば増すほど飛沫は 增加する。その上, 蒸気の流速が大になって飛沫の落下 が妨げられる結果，ますます悪いことになると思われ る。

オニブタ（ジョロバン），コマ等は飛沫を捕える邪魔 板の役目を兼ねていることは想像に難くない。コマ穴の 流速を大にすれば運ばれる飛沫も增加する一方, 蒸気は コマの天井に吹きつけられ飛沫の捕獲が增加する利点は ある。この見地よりすれば蒸気に洞流を与えるサイクロ ン式のコマを使用することが望ましい。

\section{蒸気量とコシキ肌の関係}

コシキを熱した蒝気扣よびコシキを通して伝導によっ て失われた熱に相当する蒸気は, 復水して米没叹され コシキ肌を生ずる。コシキそのるのを熱するに要する熱 量は熱し方の如何をとわず一定である。伝導によって失 われる熱は内外の温度差, 伝熱面積, 熱伝導係数, 時間に 比例し伝熱距離に逆比例する。そこで蒸気量は多くても

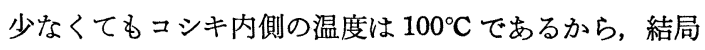
伝熱量は蒸気量に関係ないと考えてよい。また極端に蒸 気を少く例えば留め金にした場合, コシキ内面の温度は $100^{\circ} \mathrm{C}$ 以下になり得る。従って伝熱損失子幾分か減少す る。またその後で蒸気を通じた場合, 先ほどの伝熱損失 に相応した蒸気が凝縮するのであるから，常に蒸気を通 した場合と差は殆どないことになる。留め鉒はコシキに ある時間さえ同じならばコシキ肌がふえるということは ない。またコシキ肌は時間に比例するから，コシキ堀り 時間をふくめて長時間蒸すほどコシキ肌が多くなると考 えねばならない。

\section{コシキ取り時間と蒸米重量}

望:的了後, 米粒間に残存し, あるい蒸米掘り出し 作業中, 鉒の中から少し宛供給される蒸気の行方を追跡 することは極めて困難である。弥し終了後直ちに掘り出 した蒸米は大きな影響はないとしても, 下の方では順次 空気にさらされて冷却される。その際水分の蒸発を伴。 た冷却ならば周辺の残存蒸気が凝縮しても重量に差はな いが, 伝導, 輻射等によって熱が失われればコシキ肌の 成因と同じく蒸米を重くする一因となることが予想され る。しかし一方ボイラーから来る蒸気を止め, 和鉒では 栓を抜いて水を注入した場合, 鉒の中は却って陰压にな るかとも考兄られる。従ってその場合は蒸米中の残存蒸 気は鉒の中へ吸い込まれる訳である。

\section{その他考えられる要因}

不揮発性の物質を含んだ水は純水よりも沸点が高く, 生ずる蒸気は過熱蒸気である。硬水を鉒水に使用すれば 蒸気が乾くかと考学たが, 分子上年から検討すれば通常 の硬水では沸点に関する限り純水と差はない。

外気圧の差により沸点は变るが, 高気圧と低気圧程度 の圧力差で蒸米の出来を云々するのは早計である。コシ キに帆布を縛りつけて蒸しても差異の認められないこと からも,ころいう因子は大勢に影響を与えないとして取 り扱った。

蒸米の手ざわりについて, 手ざわりの良し悪しをすべ て蒸しのせい注するは疑問である。精米, 洗米等によ り表面の粗滑, 微粉の付着の有無等が手ざわりに影響し ないであろうか。また $\mathrm{Ca}^{++}, \mathrm{Mg}^{++}$, と $\mathrm{Na}^{+}, \mathrm{K}^{+}$イオ ンによって米蛋白が凝固 —膨潤するのではないかと常 々感じているが, 手ざわりという測定困難な微妙なるの を相手に研究もできないでいる。

\section{前稿の推論の妥当性の検討}

以上各種の要因を列挙したが，それらを考虑した上で 前稿の推論を再検討してみる。

蒸気の強さについては「強さ」の要因と考光得るもの は見当らない。圧力, 温度, 流量, 乾き度特よびそれら の組み合わせの中に見当らないといらことは, 例兄「強 い蒸気」が存在したとしても我々には測定不可能であ り, 制御するこるも不可能である。

コシキ内吸水については上記の諸要素は大なり小なり 影響を与兄得るものと考㝋る。しかし測定, 制御可能な丞 し米重量の近似値として前稿の式は使用でさると考えて いる。飛沫同伴の問題等は松本氏の御意見にもあるよう に，しかるべき実験装置を用いて測定することは可能で 
ある。

\section{現在の酒造技術と蒸米}

数年前, 蒸米放冷機が出現した際, 強制通風によって 冷却された蒸米によって酒質が影響されるのではないか と心配されたものである。しかし時代の要請は敢总てそ の使用に踏及切らせてしまった。その後床麴，大盛辫さ

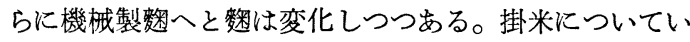

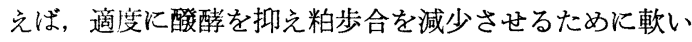
蒸米を得ようとしている所さ兄あるのが現状である。こ ろいった事情の下で「軽く完蒸」式の蒸米への要求は次 第に「一定した, 経済的な」丞しへと変っているものと 考光られる。現今はすで神泌的な「強い蒸気」の力を かりなくても良酒を安全に造り得る技術の時代であると
思らが如何であろうか。

前稿の一部汇誤りがめったので紙上を借りて訂正並に お詑び申し上げます。

第 56 巻 (896) 8.2 式は浸漬米の水分 $25 \%$ 吸水をい わゆる内 $25 \%$ としていましたのでこれを外 $25 \%$ に訂 正いたします。従って，8.2 式は

$$
\frac{(1 \times 0.5)+(0.25 \times 1)}{1.25}=0.60
$$

$10^{\circ} \mathrm{C}$ の浸漬米のコシキ内吸水は

$(100-10) / 539 \times 0.6=0.10$

米からの重量增加では, $1.25 \times 1.10=1.375$

即ち $37.5 \%$ の蒸米, 同様に $20^{\circ} \mathrm{C}$ の漬浸米では, 36.0 \%の蒸米を得る。

\section{ヨーロッパにおけるビ \\ ール醸造技術の問題点}

ヨーロッパ醉造家協会 (European Brewery Convention) の第 8 回国 際集会が昨年 5 月ウィーンで開かれ た。この会議には 1300 名以上の技 術者が参集してビール䁔造に関係す る総ゆる分野にわたっての最新の知 見が活潑に討議され，特に種々の酸 酵環境における酵母の動態とか，連 続蒸煮, 連続醱酵等に関する問題等 \{が興味のまととなった様である。

以下本集会で発表されたテーマを 列挙して会の雲囲気を味わう事にし よ5。

原料大麦関係 大麦のアルブミン について。各種大麦の吸水力につい て。 DEAE-celluloseクロマトグラ

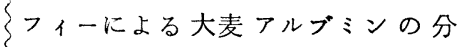
$\{$ 区。大麦胚芽及び肧乳中の $\beta$-ア ラーゼについて。大麦委員会報告。

麦芽及びホップ関係 マルティン グ中のエキス, 蛋白質変性及びマル ティング損失のコントロールについ て。新しいマルティング技術として のダブル・マルティング法。連続マ
ルティング・プラントについて。逆 相分配クロマトグラフィーによるホ ップの分析法。ホップ苦味物質及び その醇造中における変化について各 ホップ苦味物質の分離同定につい て。醱酵中の硫黄化合物について。

酵母及び醱酵関係 酵母に叔ける 醴酵効率について。酵母の Diploidizing Gene D の変換について。 Polyploid culture yeast について。 ビール酸酵中の酵素学的研究。 $S a$ cch. cerevisiae 変異株の極徽量発生 によるビールの混濁について。下面 嘸酵酵母の連続的繁殖法について。

化学関係 Gel-filtration による ビール成分の分画について。ビール の安定性に対する酵母の貢献; 酵母 のタンニン吸着能について。醸造過 程におけるタンニン類の検出及び分 類について。マルティング及び醸造 中におけるpolyphenolについて。麦 芽汁及びビール中のフラボノイド化 合物について; ポリ樹脂えの吸着。 ビール及び麦芽汁中のリピッド及び リピッド可溶性物質について。過酸 化的酸化による混濁; 酸化混濁の 前駆物質としての polyphenol 及び 蛋白質について。第 5 回分析委員会
報告。溷濁委員会報告。

酵素関係 プロテアーゼ活性の測 定法及びその応用について。マルテ イング技術に括ける蛋白分解酵素に ついて。

工学関係 連続蒸煮について。壜 の洗滌に関する諸問題。醸造工業に 於ける計画的災害対策及び工場保存 について。

御承知の如くヨーロッパで Brewing といえばビール䁔造を意味す るもので，英国人に私は Brewingの研究をやっているといえば“Oh, 必ず beer?”ときかれる程である。 従って清酒醸造に関するものはかか る国際会議の話題にはのらないので あるが，原料その他の点でビール醇 造と清酒醸造とは異っているとはい え共通する点も非常に多く以上のテ 一マ中には単にビール技術者のみな らず清酒技術者にとっても興味をそ そられるものが多い様に見受けられ た。殊に連続化等は共通した今後の テーマとして取り上げられている様 である。

上記テーマは Brewers Digest 誌 Vol. 36, No. 6 及び No.7 によっ た。 